\title{
EFFECT OF ULTRASONIC SCALING OF TEETH INVOLVED WITH PERIODONTAL DISEASE IN DOGS: A SCANNING ELECTRON MICROSCOPIC STUDY
}

\author{
EFEITO DA RASPAGEM COM ULTRASSOM DE DENTES ENVOLVIDOS COM \\ DOENÇA PERIODONTAL EM CÃES: UM ESTUDO MICROSCOPIA ELETRÔNICA \\ DE VARREDURA
}

\author{
Moacir Santos de LACERDA ${ }^{1}$; Antonio Carlos ALESSI ${ }^{2}$ \\ 1 Professor, Doutor, Department of Veterinary Surgery and Anestesiology, Faculty of Veterinary Medicine. University of Uberaba, \\ Uberaba, MG, Brazil. moacir.lacerda@uniube.br; 2. Professor, Doutor, Department of Veterinary Pathology, FCAV/UNESP, \\ Jaboticabal, SP, Brazil.
}

\begin{abstract}
Scaling using ultrasonic dental equipment was performed on 20 teeth extracted from dogs with advanced periodontal disease, under clinical indication. The surgical extraction of the teeth, which already showed mobility, carried out by means of a lever, tried not to touch the radicular surface which would be assessed. The mesial surface of the cervical root region was used for verifying the effect of the ultrasonic scaling and the distal surface was maintained intact for control. After treatment, the teeth were sectioned, separating the region of interest, and these were fixed in glutaraldehyde, dried with a critical point dryer and metallized for observation under electronic scanning microscopy. The presence of plaque, biofilm and rod cells on the non-treated surface was quite characterized. On the surface submitted to treatment by ultrasound, it was possible to see areas with the removal of all the dental calculus, and areas with exposed naked dentine and showing open dentinal tubules. It was possible to observe also the occasional presence of bio-film and rod cells penetrating the dentinal tubules. No harm to the dentine was observed. Thus, ultrasonic scaling showed to be useful in the purpose of removing plaque and can be better developed. Future studies are necessary to establish a comparison with other methods of scaling.
\end{abstract}

KEYWORDS: Dog. Periodontal disease. Scaling.

\section{INTRODUCTION}

Periodontal disease is the most frequent lesion of the oral cavity in dogs. It affects the animals' health and quality of life and is an important cause of tooth loss. Bacterial plaque is regarded as the most important etiological factor in the development of destructive periodontal disease (COLMERY; FROST, 1986; DOMINGUES et al., 1999; HARVEY; EMILY, 1993; GIOSO, 2007). Because of this, surgical treatment is frequently employed and more efficient techniques are being tested worldwide (BREININGER et al., 1987).

In periodontal disease, the root surface is exposed to the sub gingival environment and micro flora. The exposure to crevicular fluid, as well as to enzymes and metabolites produced by sub gingival plaque bacteria, induces physicochemical and structural alterations of the radicular cementum (ADRIAENS et al., 1988). The exposed radicular cementum is a thin, often discontinuous barrier between the underlying dentin and the oral environment (ADRIAENS et al., 1988).

In the radicular hard tissues (cementum and radicular dentin) of periodontally diseased teeth, the presence of invading bacteria has occasionally been reported (ADRIAENS et al., 1987). Using electronic scanning microscopy and light microscopic techniques it was possible to perceive bacteria invading the radicular cementum and the dentinal tubules of the radicular dentin of periodontally diseased, caries-free human teeth (ADRIAENS; DE BOEVER, 1986).

As part of dental prophylaxis, periodontal cleaning and therapy procedures, ultrasonic scalers are frequently used in veterinary medicine to remove calculus (BRINE et al., 2000).

Ultrasonic scalers are used extensively in human and veterinary dentistry because they are effective in removing dental calculus and are comfortable to use. Ultrasonic waves are generated by magnetostrictive or piezoelectric equipment. Their action is based on the oscillation produced by an electromagnetic field created by an electrical current. The oscillatory frequency can range from 20,000-40,000 cycles per second, depending on the apparatus used (FRAGUELA et al., 2000).

The purpose of this study was the assessment of the effect of ultrasonic scaling of teeth in dogs with periodontal disease using electronic scanning microscopy. 


\section{MATERIALS AND METHODS}

The sample used in this study is constituted of 20 inferior and superior incisive teeth showing advanced periodontal involvement (grade III mobility). Due to this, extraction was clinically indicated. These teeth were obtained from dogs of various breeds, from 3 to 10 years old, their weight varying from 1.9 to $13.0 \mathrm{~kg}$, males or females, coming from surgical appointments in veterinary hospitals. The surgical extraction of the teeth, with the use of a lever tried not to touch the radicular surface that would be assessed. This was possible due to the mobility already installed.
LACERDA, M. S.; ALESSI, A. C.

The teeth were fixated in $10 \%$ formalina after extraction. The plaque was stained with basic fuch $\sin ^{1}$.

The mesial surface of the root cervical portion of each tooth was submitted to scaling by ultrasonic dental equipment (treated surface) and the distal surface was maintained intact, as a control (non-treated surface).

In order to carry out scaling, a tip was attached to the piezoelectric ultrasonic scaler ${ }^{2}$ of frequency variable between $30-40 \mathrm{kHz}$. The tooth was fixed by means of a straight kelly hemostatic forceps its apex in the region. The dental surface was scaled until it was considered clinically clean by visual examination by the same researcher.

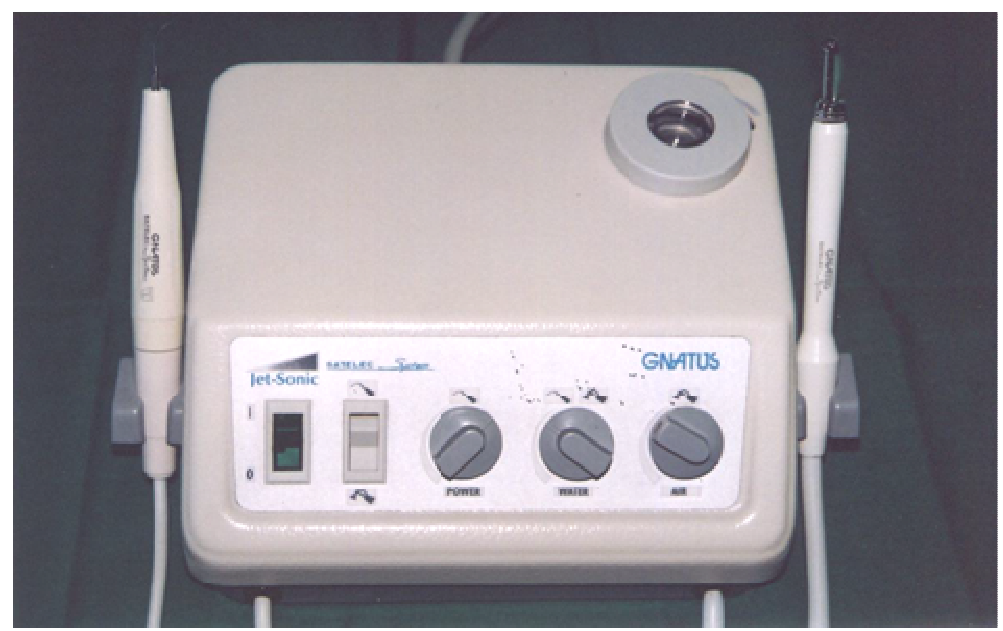

Figure 1. Ultrasonic equipment used in the study

The percentage of bare dentin was obtained considering the whole treated area of the histological sections, according to the following:
a) $0 \%$
b) $25 \%$
c) $50 \%$
d) $75 \%$
e) $100 \%$

The cervical part was then sectioned lengthwise in a mesial/distal half (Figure 2). The two halves were fixed in glutaraldehyde at $2 \%$ and conserved at a temperature of $8^{\circ} \mathrm{C}$. Following this, they were fixed in osmium tetroxide at $1 \%$ in a phosphate buffer $0.2 \mathrm{M}(\mathrm{pH} 7.4)$ for four hours, washed three times in a buffer solution and after this, they were dried by means of a critical point dryer EMS 850. In the next step they were attached to the SEM stub with double-sided sellotape, sputter-coated with gold/palladium and viewed in a JEOL-JSM 5410 model, at 15KV.
The teeth were sectioned transversally, by means of a diamond disc under a constant jet of water, leaving aside the entire crown and the apical third of the root.

${ }^{1}$ Replasul "T" - Iodontosul - Porto Alegre - RS.

${ }^{2}$ Jet-Sonic - Gnatus - Ribeirão Preto - SP

All analysis was performed by use of a statistical software program ${ }^{1}$. Mean $(+\mathrm{SD})$ was determined for surface (control and treated). In order to determine differences between means Student's paired t-test was used. Values of $p<0.05$ were considered significant. 

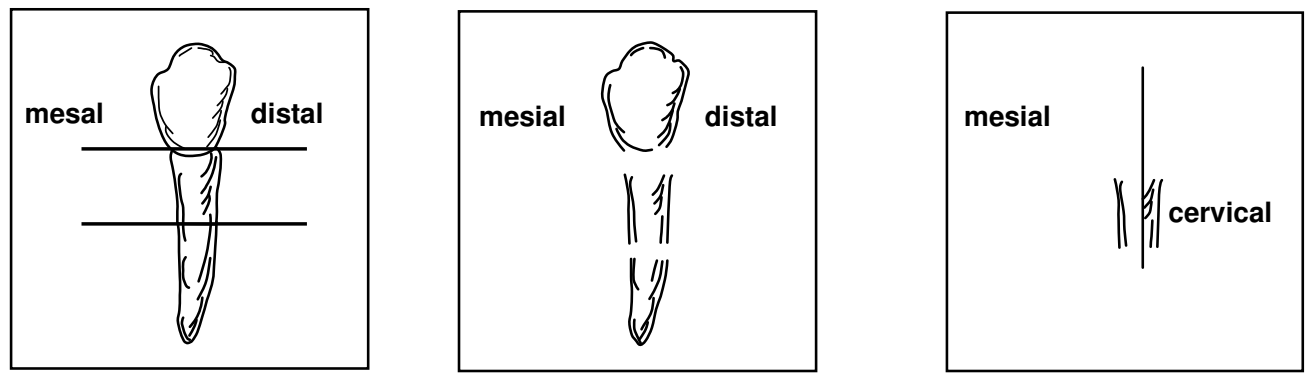

Figure 2. Diagram that summarizes the preparation of the dogs' teeth samples for electronic scanning microscopy (ESM).

\section{RESULTS}

Table 1. Teeth according to percentage (\%) of dentin bare root structure in the region treated and control.

\begin{tabular}{ccc}
\hline Teeth & Control & Treated \\
\hline 1 & 0 & 25 \\
3 & 0 & 0 \\
4 & 0 & 0 \\
5 & 0 & 0 \\
6 & 0 & 100 \\
7 & 0 & 100 \\
8 & 0 & 50 \\
9 & 0 & 0 \\
10 & 0 & 0 \\
11 & 0 & 0 \\
12 & 0 & 0 \\
13 & 0 & 0 \\
14 & 0 & 75 \\
15 & 0 & 25 \\
16 & 0 & 25 \\
17 & 0 & 50 \\
18 & 0 & 25 \\
19 & 0 & 25 \\
20 & 0 & 75 \\
$\bar{X}$ & 100 & 100 \\
\hline $\mathbf{D p}$ & 5.00 & 33.75 \\
\hline
\end{tabular}

$\bar{X}=$ média $\quad \mathrm{dp}=$ desvio padrão

Student's t-test for the comparison of two means

Control $x \quad$ Treated $p<0.05^{*}(\mathrm{p}=0.0054)$

All the twenty chosen teeth showed the same pattern of calculus as regards extension. The removal of the calculus from the extracted teeth, using ultrasonic equipment, did not encounter any obstacles, as their fixation by means of the kelly forceps was sufficient to keep them firm.

The perception of the clinically clean surface was also not difficult, as the equipments pincers skimmed over more easily. Visualization did not require a magnifying glass. The method employed in the preparation of the teeth for observation under SEM also showed to be adequate, due to the quality of the images obtained.

The non-treated surfaces are shown to be irregular, and the deposits of calculus are clearly seen (Figures 3, 4 and 5). Bacteria and detritus were also present. The limits between the treated and non-treated surfaces were very clear (Figure 5) and it is possible to see bacterial plaque and naked dentine interposed by cementum. A piece of animal's fur was also found, partially incrusted in a calculus (Figure 5). The interface between the dental 
calculus and the cementum (Figures $4 \mathrm{~A}$ and $\mathrm{B}$ ) could be identified in most cases.

Presence of cementum obstructing the dentinary tubules and in some areas the presence of open dentinal tubules after scaling (Figure 6A). At higher magnification, the surface of the dentin was covered in a thin layer of amorphous material. This layer was thought to be equivalent to the smear layer. It is possible to note the presence of open dentinal tubules and the removal of the calculus in the treated area. The necrotic cementum was not removed completely.

The bacterial plaque on the studied teeth under non-treated surface shows clearly the presence of rod shaped bacteria invading the dentinal tubules and becoming part of the tooth biofilm (Figures 7A and B).

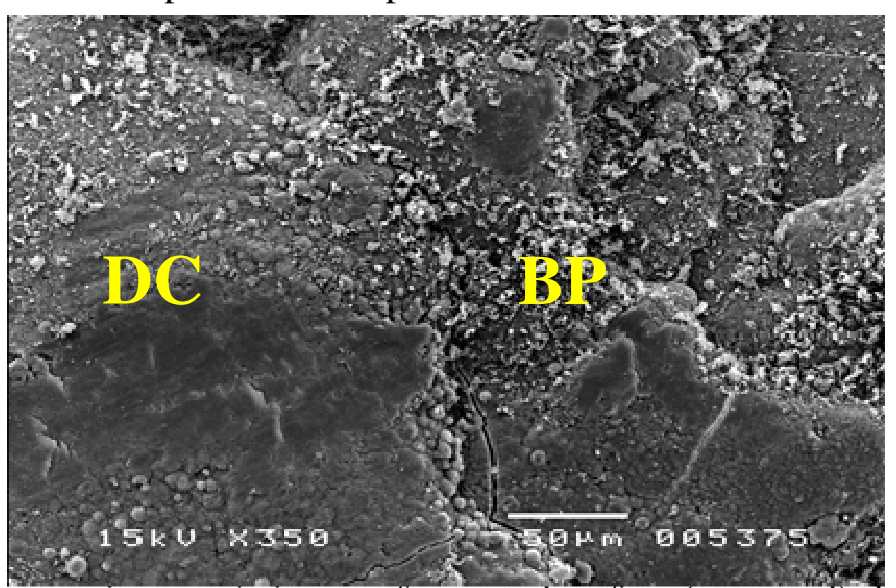

Figure 3. Scanning electron microscopic image of a control surface (untreated) showing the mesial root surface of a dog's incisive tooth with periodontal disease. Observe the presence of the dental calculus (DC) and bacterial plaque (BP).

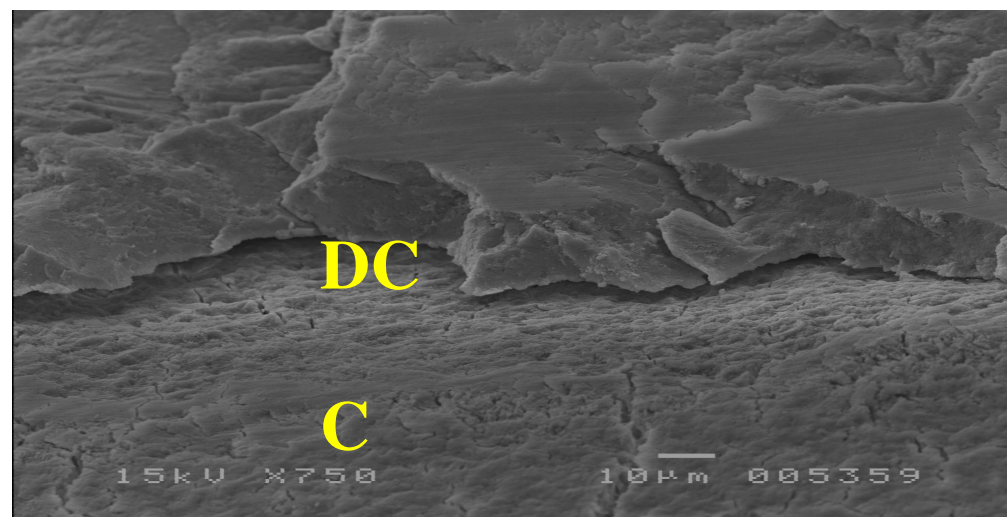

Figure 4. Electron micrography of the root of a dog's incisive tooth submitted to scaling with curette showing the transversal section of the sub gingival dental calculus (DC) adhered to the cementum (C) on the control face.

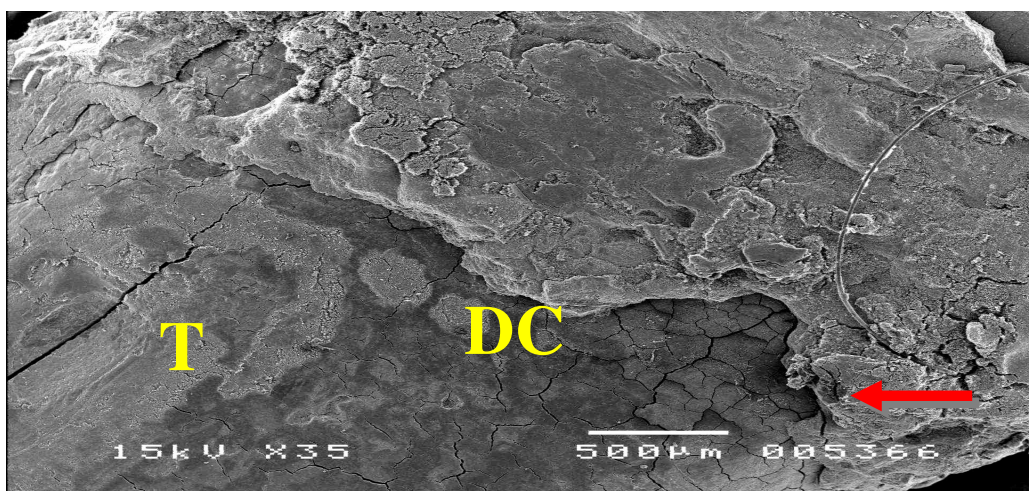

Figure 5. Electron micrography of the root of a dog's incisive tooth with periodontitis submitted to scaling with ultra-sound equipment (longitudinal cut) showing the limit between the treated $(\mathrm{T})$ and non-treated areas. Note the presence of the dental calculus (DC) and animal fur (arrow). 


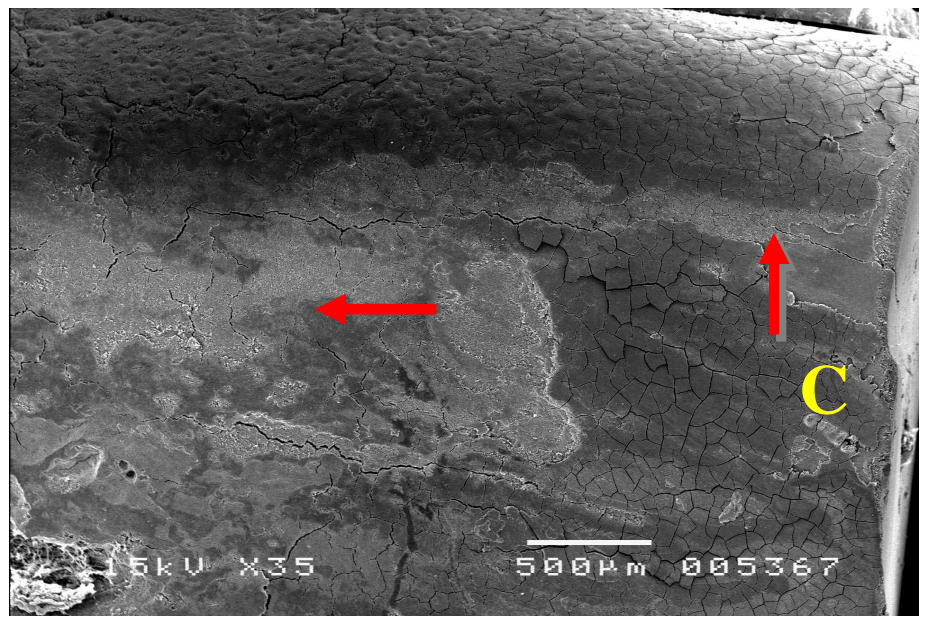

Figure 6. Electron micrography of the root of a dog's incisive tooth with periodontitis submitted to scaling with ultra-sound equipment, sowing the aspect of the treated face. Note the presence of cementum (C) blocking the dentinary tubules and open dentinal tubules (arrow) without the presence of bacteria.
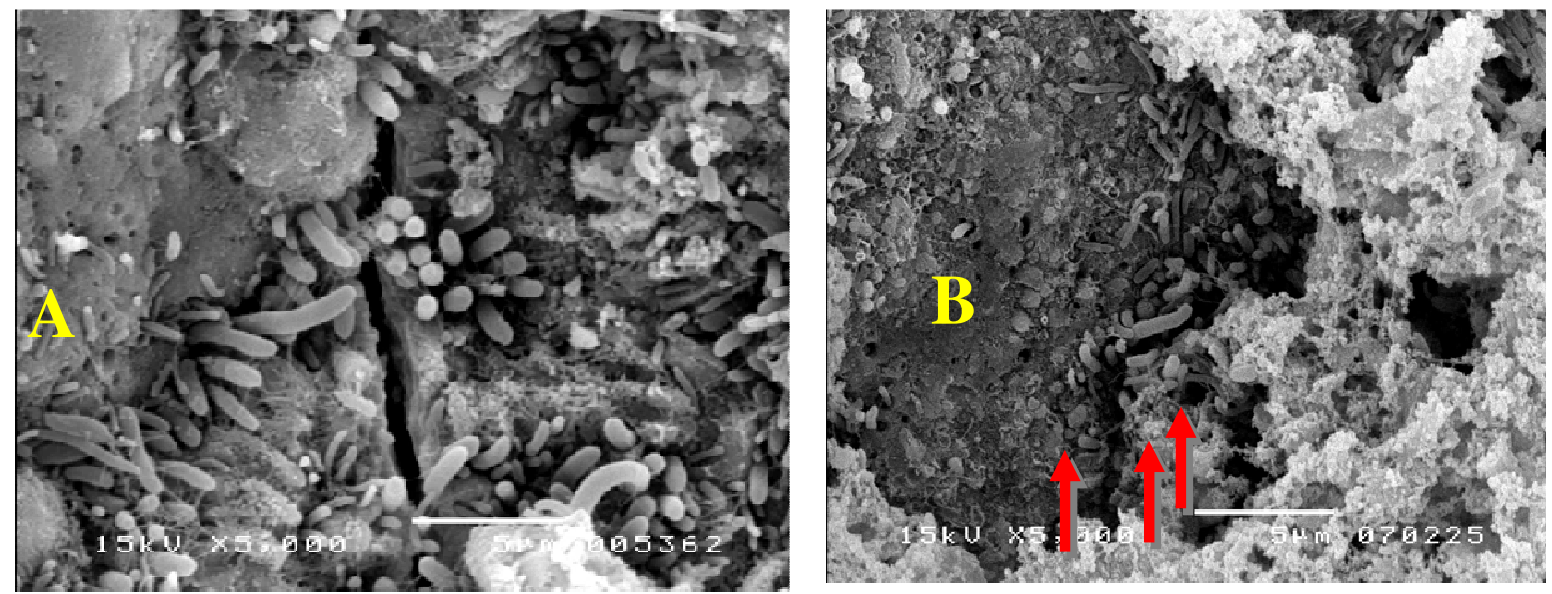

Figure 7A and B. Electron micrography of the root of a dog's incisive tooth with periodontitis submitted to scaling with ultra-sound equipment, showing the presence of bacterial plaque (limit between the treated and non-treated areas). Observe bacteria penetrating the dentinal tubules (arrow) and open dentinal tubule (double arrow).

\section{DISCUSSION}

In the clinical treatment of gingival inflammation, Black (1886) already referred to the importance of the removal of deposits adhered to the teeth. However, the possibility of obtaining results that are efficient and safe is still questionable today (BORGHETTI et al., 1987; MISHRA, PRAKASH, 2013).

These doubts specifically those which refer to dental scaling and radicular smoothing, are the ones that offer incentive to the search for knowledge about the characteristics that the radicular structures take on when submitted to therapy, still much used today (ARMITAGE et al. 1984; KISHIDA, SATO, ITO, 2004; FICHTEL et al., 2008).

The effects of ultrasound scaling on teeth involved in periodontal disease in dogs were studied using SEM. Observation of the treated surface areas showed alterations which ranging from areas which were histologically clean, protected or not by cementum, to others showing naked dentine contaminated or not usually in hard to reach, deep areas. The treated areas that showed to be histologically clear of plaque or microorganisms represented $80 \%$ (BRINE et al., 2000).

The analyses of the samples under electronic scanning microscopy allowed for assessment of the control and treated surfaces of the teeth regarding the presence of bacterial plaque, the action of the instruments that were used, the exposure of the dentinary tubules after treatment; it also allowed for the observance of the interface between calculus and treated area and the penetration of bacteria in the dentinary tubules (ADRIAENS et al., 1987; BERGENHOLTZ; BABAY, 1998). 
The average of $33.75 \%$ of bare dentin for the treated surface (Tab. 1) and the largest quantity of remaining cement may happen due to the amount of time probe the ultrasound in the root structure. This amount of time is enough to eliminate the dental calculus (clean surface), but not enough to remove the cement. The objective of this work was not to determine the time of action of the device, but to observe the treated surfac regarding its cleanliness, which is the parameter used in clinical routine.

The tip of the ultrasound scratches the surface, leaving a smear layer in some areas, and does not cause physical harm to the teeth (Figures $6 \mathrm{~A}$ and $\mathrm{B})$. Presence of open dentinary tubule shows the total removal of dental calculus and necrotic cementum.

Damage and cutting of dentin in human teeth results in a rapid movement of fluid through the dentinal tubules (BRÄNNSTRÖM, 1984). Although the hydrodynamics of dog dentin are unknown, it is likely that fluid movement within dentin is essential to its normal function, as in other species. The greatest movement of fluid occurs in large, open dentinal tubules. The presence of a smear layer or pellicle does not necessarily reduce the sensitivity of dentin (BRÄNNSTRÖM, 1992). Another advantage of the smear layer is the ability to reduce the permeability of debris to the dentinal tubules (KIM et al., 2002). A smear layer of small particle size prevents bacteria from penetrating the dentine in studies of human teeth (NAGOAKA et al., 1995). Studies carried out in extracted human teeth have shown that dentinal tubules are the major conduits for fluid diffusion across dentin (PASHLEY, 1992; HOLLAND, 1994). Although ultrasound scaling creates a partial smear layer, it would be wise to minimize injury to the dentine during periodontal treatment.

Ultrasound does not remove necrotic cementum entirely, suggesting the use of additional curettes for scaling. The bacteria invading the dentinal tubules (Figures 7A and 7B) suggest the presence of an perio-endo lesion in the researched teeth. A removal of the entire cementum and part of the contaminated dentine exposes dentinal tubules and the bacterial re-colonization could allow the entrance of bacteria in the tubules.

Dentin is a vital, dynamic tissue and this paper illustrates the small amount of damage to dentin during scaling with ultrasound equipment.

The results obtained in this study "in vitro", taking into consideration the electronic scanning microscopy of dog's teeth showing periodontal disease, allowed to conclude that ultrasound treatment does not dislodge bacteria from the remaining contaminated cementum or from the deeper levels of dentine, specially the dentinary tubules.

The results obtained in this paper stimulate more research, such as regarding the influence of periodontal diseases on the endo-periodontal lesion, the use of acid conditioning of the radicular surface for assessment after scaling and studies on the bactericide concentration of antimicrobials on the radicular surface.

The continuation of this line of research would bring benefit in the reproduction of situations in which the dog may become a model for studies that focus on knowledge applicable to human beings.

RESUMO: A raspagem com ultrasom odontológico foi usado em 20 dentes extraídos de cães com doença periodontal avançada. A face mesial da raiz foi para a verificação da atuação do instrumento e a distal como controle. A avulsão cirúrgica dos dentes com o uso de alavanca procurou não alterar a superfície radicular a ser avaliada. Após tratamento, os dentes foram preparados para a microscopia eletrônica de varredura. Observou a presença de biofilme e bastonetes penetrando nos túbulos dentinários. A remoção de todo o cálculo dentário e áreas com exposição de dentina nua e com túbulos dentinários abertos. A raspagem fornece uma camada de smear layer. Não se verificou dano a dentina. A raspagem com ultrassom é útil e futuros estudos são requeridos para estabelecer comparativo com outros métodos de raspagem.

PALAVRAS-CHAVE: Cão. Doença periodontal. Raspagem.

\section{REFERENCES}

ADRIAENS, P. A.; EDWARDS, C. A.; DE BOEVER, J. A.; LOESCHE, W. J. Ultrastructural observatons on bacterial invasion in cementum and radicular dentin of periodontally diseased human teeth. J. Periodontol., Chicago, v. 59, n. 8, p. 493-503, 1988. 
ADRIAENS, P. A.; DE BOEVER, J. A.; LOESCHE, W. J. Bacterial invasion in toot cementum and radicular dentin of periodontally diseased teeth in humans. J. Periodontol., Chicago, v. 59, n. 4, p. 222-230, 1987.

ADRIAENS, P. A.; DE BOEVER, J. A. Ultrastructural study of bacterial invasion in roots of periodontally diseased, caries-free human teeth. J. Dent. Res., Alexandria, v. 65, p. 770, 1986.

ARMITAGE, G. C. Bases biológicas da terapia periodontal. São Paulo: Santos, 1984. 256p.

BERGENHOLTZ, A.; BABAY, N. Scanning electron microscopy of the root surface texture of extracted periodontally diseased teeth following various etching and chelating regimens. Int. J. Periodont. Rest. Dent., Chicago, v. 18, p. 171-179, 1986.

BORGHETTI, A.; MATTOUT, P.; MATTOUT, C. How much root planning is necessary to remove the cementum from the root surface Int. J. Periodont. Rest. Dent., Chicago, v. 7, n. 4, p. 23-29, 1987.

BRÄNNSTRÖM, M. Communication between the oral cavity and the dental pulp associated with restorative treatment. Oper. Dent., Los Angeles, v. 9, p. 57-61, 1984.

BRÄNNSTRÖM, M. Etiology of dentin hypersensitivity. Proc. Finn. Dent. Soc. (Suppl), Helsinki, v. 88, n. 1, p. 7-13, 1992.

BREININGER, D. R.; O'LEARY, T. J.; BLUMENSHINE, R. V. Comparative effectiveness ultrasonic and hand scaling for the removal of subgengival plaque and calculus. J, Periodontol., Chicago, v. 1, n. 58, p. 9-18, 1987.

BRINE, E. J.; MARRETTA, S. M.; PIJANOWSKI, G. J.; SIEGEL, A. M. Comparison of effects of four different power scalers on enamel tooth surface on the dog. J. Vet. Dent., Philadelphia, v. 17, n. 1, p. 7-21, 2000.

COLMERY III, B.; FROST, P. Periodontal disease: etiology and pathogenesis. Vet. Clin. North Am. Small Anim. Pract., Philadelphia, v. 16, n. 5, p. 817-833, 1986.

DOMINGUES, L. M.; ALESSI, A. C.; CANOLA, J. C.; SEMPRINI, M. Tipo e freqüência de alterações dentárias e periodontais em cães na região de Jaboticabal, SP. Arq. Bras. Med. Vet. Zootec., Belo Horizonte, v. 51, n. 4, p. 323-328, 1999.

FICHTEL, T.; CRHA, M.; LANGEROVÁ, E.; BIBERAUER, G.; VLA ÍN, M. Observations on the effects of scaling and polishing methods on enamel. J. Vet. Dent., Philadelphia, v. 25, n. 4, p. 231-235, 2008.

FRAGUELA, J. L. V.; VALLÈS, M. A. V.; CALVO, L. J. E. Effects of ultrasonic dental scaling on pulp vitality in dog: an experimental study. J. Vet. Dent., Philadelphia, v. 17, n. 2, p. 75-79, 2000.

GIOSO, M. A. Odontologia para o clínico de pequenos animais. Barueri: Manole, 2007. 63p.

HARVEY, C. E.; EMILY, P. P. Small Animal Dentistry. St. Louis: Mosby - Year Book, 1993; 413p.

HOLLAND, G. R. Morphological features the dentin and pulp related to dentin sensitivity. Arch. Oral Biol. (Suppl), Philadelphia, v. 39, p. 3-11, 1994.

KIM, S.; TROWBRIDGE, H.; SUDA, H. Pulpal reaction to caries and dental procedures. In: Cohen S, Burns RC, eds. Pathways of the pulp. $8^{\text {th }}$ ed, St. Louis:Mosby; p. 411-476, 2002.

KISHIDA, M.; SATO, S.; ITO, K. Comparison of the effects of various periodontal rotary instruments on surface characteristics of root surface. J Oral Sci., Tokyo, v. 46, n. 1, p. 1-8, 2004. 
MISHRA, M. K., PRAKASH, S. A comparative scanning electron microscopy study between hand instrument, ultrasonic scaling and erbium doped:Yttirum aluminum garnet laser on root surface: A morphological and thermal analysis. Contemp. Clin. Dent., Mumbai, v. 4, n. 2, p. 198-205, 2013.

NAGOAKA, S.; MIYAZAKI, Y.; IWAMOTO, Y.; KITANO, M.; KAWAGOE, M. Bacterial invasion into dentinal tubules of human vital and non-vital teeth. J. Endod., Philadelphia , v. 21, p. 70-73, 1995.

PASHLEY, D. H. Dentin permeability and sensivity. Proc. Finn. Dent. Soc. (Suppl), Helsinki, v. 88, n. 1, p. 31-37, 1992. 